\section{vate Matimes}

June 2-6. Tissue Culture Association Annual Meeting. New Orleans, LA. Info: Frederick H. Kasten, Dept. of Anatomy, Louisiana State Medical Center, 1100 Florida Ave., New Orleans, LA 70119

June 2-7. Mechanisms of DNA Damage and Repair: Implications for Carcinogenesis and Risk Assessment. Gaithersburg, MD. Info: Kathy Stang, A353 Physics Bldg., National Bureau of Standards, Gaithersburg, MD 20899

June 3-7. United Nations Symposium on Importance of Biotechnology for Economic Development. Szeged, Hungary. Info: Industry and Technology Division, U.N. Economic Commission for Europe, Palais de Nations, CH-121 I Geneva 10, Switzerland

June 3-7. Twenty-One Years of DNA Repair. Upton, NY. Info: Anne Baittinger, Public Relations Office, Brookhaven National Laboratory, Upton, NY 11973

June 4-8. Bio Expo 85. Paris. Info: Societe SEPFI, 8 rue de la Michodiere, 75002, Paris, France

June 9-15. ACHEMA 85. Frankfurt, F.R.G. Info: DECHEMA, Organization ACHEMA, P.O. Box 9701 46, D-6000 Frankfurt 97, F.R.G.

June 12-16. 25th Meeting of the Phytochemical Society of North America (featuring a forum on biotechnology and phytochemistry). Pacific Grove, CA. Info: Bock G. Chan, Plant Protection Phytochemistry, WRRC, ARS, USDA, 800 Buchanon St., Berkeley, CA 94710

June 18-20. Symposium on Microbial Biomass Proteins: Nutritional, Safety and Economic Aspects. Waterloo, Ont., Canada. Info: Institute for Biotechnology Research, University of Waterloo, Waterloo, Ont. Canada N2L 3G1

June 25-27. New Technology in Biotechnology. London. Info: Macmillan Conferences and Exhibitions, 4 Little Essex St., London WC2R 3LF, U.K.

June 25-28. International Symposium on Forest Utilization of Municipal and Industrial Wastewater and Sludge. Seattle, WA. Info: Kathi Grier, College of Forest Resources
AR-10, University of Washington, Seattle, WA 98195

\section{JuYY MATINGS}

July 15-19. Biotechnology for the Americas II: Applications in Tropical Agriculture. San Jose, Costa Rica. Info: James W. Rowe, American Association for the Advancement of Science, 1776 Massachusetts Ave., NW, Washington, D.C. 20036

July 17-19. Photosynthesis and Genetic Engineering. Oxford, U.K. Info: Meetings Officer, The Biochemical Society, 7 Warwick Court, London WCI5 5DP, U.K.

July 31-Aug. 2. Molecular Biology Summer Symposium. University Park, PA. Info: Robert A. Schlegel, 208 South Frear Laboratory, Pennsylvania State University, University Park, PA 16802

\section{Aneust magnives}

Aug. 3-9. Annual Meeting of the Society for Industrial Microbiology. Boston, MA. Info: Ann Kulback, SIM Headquarters, 1401 Wilson Blvd., Arlington, VA 22209

Aug. 12-16. Gordon Conference on Applied and Environmental Microbiology. New London, NH. Info: J. Gregory Zeikus, Chairman, Michigan Biotechnology Institute, 276 Bessey Hall, Michigan State University, East Lansing, MI 48824

Aug. 12-16. 7th International Conference on the Global Impacts of Applied Microbiology. Helsinki, Finland. Info: H. G. Gyllinbenberg, Microbiology Dept., University of Helsinki, SF-00710, Helsinki 71, Finland

Aug. 27-31. 9th International Symposium on Continuous Culture of Microorganisms: Continuous Cultivation in Biotechnology and Environment Conservation. Prague, Czechoslovakia. Info: B. Sikyta, Institute of Microbiology, 14220 Praha, Krc, Czechoslovakia

\section{covinas}

June 5-7. Biochemical Engineering Fundamentals. Washington, D.C. Info: James E. Bailey, BRE Systems, 1665 East Mountain St., Pasadena, CA 91104
June 15-22. Biotechnology: Japanese Fermentation Technology (a study mission to Japan including attendance at Biotex '85). Info: Hideaki Hashizume, General Manager, Technology Transfer Institute, One Penn Plaza, Suite 1411, 250 West 34th St., New York, NY 10119

June 17-19. Introduction to BIONET: The National Computer Resource for Molecular Biology. Piscataway, NJ. Info: Selma Gitterman, Director, Continuing Professional Education, Waksman Institute of Microbiology, Rutgers, The State University, P.O. Box 759, Piscataway, NJ 08854

\section{Dreantwe anuess}

Genetic Engineering Inc. (Denver CO) elected Gary D. Boring president and chief operating officer. Boring had been with Liposome Technology (Menlo Park, CA). He succeeds Charles Srebnik, who remains chairman and chief executive officer.

Life Technologies (Chagrin Falls, $\mathrm{OH}$ ) elected M. James Barrett president.

Bio-Response (Hayward, CA) appointed Alfred Daniel president and chief operating officer.

HP Genenchem (South San Francisco, CA) named Robert D. Board president, succeeding Ivan L. Crocket, who returns to Hewlett-Packard. Board had been group manager of engineering for the HP Analytical Products Group.

The Liposome Company (Princeton, NJ) named Leon M. Rosenson vice president of administration, Sterling C. Johnson vice president of business development, and Robert L. Suddith vice president of operations. The company also appointed Michael V. W. Bergamini director of opthalmic research and Thomas D. Becze director of regulatory affairs and quality assurance.

Genentech (South San Francisco, CA), named Brian C. Cunningham general council, William W. Higgins director of human resources, and Mark B. Hirsch vice president of business development.

Genex Corp. (Rockville, MI)) appointed Louis E. Windecker senior vice president for operations. 